\title{
Innovation and Social Change in the Vale of Kashmir, circa 900-125 OC.E.
}

\author{
John Nemec \\ iti prakațito mayā sughața eșa mārgo navo mahāgurubhir ucyate sma śiva- \\ drștisisāstre yathā|
}

Thus I have set forth this new (nava), easy path as it was explained by my distinguished teacher [Somānanda] in the śāstra, [entitled] the Śivadrșți.

İsvarapratyabhijñākārikās of Utpaladeva at 4.16ab

\section{Introduction}

It is well known that religious agents in premodern South Asia appealed to the purported timelessness and transcendence of their scriptural sources to secure not only their legitimacy but also that of the ideas found in them. Equally well known - in no small part due to the work of Alexis Sanderson on the social history of Śaiva and other religious traditions in early-medieval Kashmir and elsewhere-is the fact that premodern South Asian religions do not appear as unchanging and immobile traditions in social stasis. Quite the opposite: the various religious traditions of medieval South Asia were nothing if not innovative in idea and practice, most notably in their literary productions. These myriad religious traditions, moreover, had a measurable and not insignificant influence on contemporaneous social life.

In beginning to address the question of religious change in premodern South Asia I would like not merely to point out that the religious practitioners of the day were surely able to distinguish new religious, and other, ideas and practices from received tradition - just as we are today - a fact that itself calls into question the reification of the sort of social stasis and lack of historical awareness posited in previous Indological scholarship. ${ }^{1}$ I also will argue that

1 Monier-Williams (1891, 38-39), for example, suggested that Brahminical theology preempts

(C) JOHN NEMEC, 2020 | DOI:10.1163/9789004432802_014

This is an open access chapter distributed under the terms of the CC BY-NC 4.o license. 
a self-conscious, emic theory or explanation of scriptural authority and social change may be found in the history of religions in premodern Kashmir. I wish to examine the significance of novelty, of innovation, as it was conceived by the authors I propose to place under study, and to identify its role in establishing, or challenging, religious authority in the period in question, all of which I will do by exploring an exemplar that illustrates what I suggest should be taken as a maxim in the study of South Asian religions (and religion more generally), namely, that change is not inimical to religion, even if particular religious agents are not infrequently inimical to change. ${ }^{2}$

In particular, I propose to examine selected writings of some among the most prominent of the Śaiva tantric "post-scriptural" authors of the Kashmir Valley, who thrived there in the period reserved by the title of the present essay. They include Somānanda (circa 900-950), Utpaladeva (circa 925-975), and Abhinavagupta (circa $975^{-1025}$ ), as well as Jayaratha (early 13th C.E.), the author of the Tanträlokaviveka commentary on the Tantrāloka (hereafter TĀV and $\mathrm{TA}$, respectively). Their textual contributions are properly associated with what continues, sometimes, to be labeled "Kashmiri Shaivism,"3 and they offer an important opportunity to reevaluate the nature of various sources of reli-

any proper appreciation of history. MacDonell, in turn, both reiterates this position and adds to it a second claim regarding what he calls the "total lack of the historical sense" in premodern Indian literature: he claims that historical events in premodern South Asia were insufficient to trigger the cultivation of a properly historical consciousness. See MacDonell [1900] $1962,8-9$. This pair of views exemplifies the two types of arguments that earlier Indologists have made regarding the supposed ahistoricality of premodern South Asian works: Scholars often suggested either that the authors of premodern Sanskrit works held theoreticalmainly religious - views that precluded them from taking interest in historical concerns; or, they argued that historical events in premodern South Asia transpired in ways that preempted the possibility of a properly historical response to them.

2 Scholars in the academy have given new attention to the question of the place of change in religion in recent years. Jonathan Edelmann, formerly of Mississippi State University and now at the University of Florida, has suggested, in an unpublished précis of concerns addressed by four panelists of a session of the 2011 American Academy of Religion National Meeting entitled "Authorizing Theologies," that the question to hand was a matter of "newness," of novelty, and of "authorizing" such novelty in the language of "theology," with the shared hypothesis of all the panelists being that the various theological formulations they placed under examination each sought to "recast and re-contextualize influential concepts and arguments from earlier traditions" (to quote from the panelists' description of the session). Some of the products of this panel may be found in a special issue of the International Journal of Hindu Studies, for which see Edelmann 2014. The present essay constitutes a response to and an engagement with the broader theme first engaged by these scholars at the AAR Annual Meeting in question.

3 It is well known by now that this term is something of a misnomer, because it is both overly specific geographically and overly general doctrinally. See Dyczkowski 1987: 222-223. 
gious authority in premodern South Asia, as well as the manner of establishing and deploying such authority in practice in India's premodernity.

This is so, firstly and primarily, because the authors in question explicitly wedded themselves to the notion that novelty, the production of something new, was not only acceptable, but was an asset to their religion. This they maintained over and against the ethos of Vedic religious authority, which was defined by its claim to offer a kind of knowledge that was beyond question, its infallibility guaranteed by the purported timelessness and authorlessness of the Vedic scriptures themselves. Secondly, and related to this, they lived and wrote in the Valley at a time when Kashmir was economically dynamic and culturally and religiously pluralistic, and was perhaps the most active center of Sanskrit literary production in the Indian sub-continent not only in its day, but in Indian history (after the time of the Guptas). ${ }^{4}$ Indeed, the bibli-

4 Royal patronage certainly did much to cultivate this cultural richness, as the many Kashmiri contributions in poetry and aesthetic theory illustrate, these of course being important concerns of the premodern South Asian court; but this was not the only catalyst. Five additional elements served to make such cultural production possible. These include:

(1) The relative security of Kashmir. Closing the famed "gates" to the Valley-the mountain passes or $d v \bar{a} r a s$ - offered reliable protection from outside military interference, though this did not help quell internal military threats, as the Rājataranginī makes abundantly clear.

(2) This does not mean, however, that Kashmiris were unaware of outside military and other influences. One anecdote illustrates as much: to my knowledge the earliest use in Sanskrit of the term turuṣka appears in a Kashmiri work, the famed Kutțanimata of Dāmodaragupta; and the term frequently appears in later Kashmiri works such as the Räjataranigin̄ and the Kathāsaritsāgara. So much signals the second catalyst: cosmopolitanism, or a cognizance of the wider world and significant contact with it. Foreign invaders were long kept at bay, to be sure; but, simultaneously, scholars and merchants regularly were given leave to visit the Valley from the plains of India and from as far afield as Central Asia and China, and possibly beyond. Perhaps most notably, Tibetan Buddhist pilgrims frequented Kashmir in order to study in the Valley's thriving monasteries, which were influential in the period in question even if relatively few archaeological traces of them have survived to the present day.

(3) Next, the extensive and longstanding cross-pollination of Hindu and Buddhist thought did much to enrich humanistic thinking in the Valley in the period under study; it helped that, with relatively few exceptions, the kings of Kashmir supported a healthy religious diversity in the Valley. (Harșa of course is one exception to the general rule that Kashmiri kings, and members of the court, patronized various traditions simultaneously, and certainly lived up to the Dharmaśāstric norm of leaving religion alone short of the emergence of egregious concerns therewith.) I would count this intellectual and religious pluralism the third productive factor in Kashmiri intellectual and cultural history.

(4) A fourth influence was economic: global trade along the nearby Silk Road is likely to have contributed to the Valley's material prosperity, which would have facilitated the cultivation of Kashmir's cultural wealth (though more work is needed better to understand this dimension of Kashmiri social life); and the Valley itself, with its large tracts of arable land, was agriculturally largely self-sufficient. 
ography of Kashmiri contributions, one feels, is practically asymptotic to that of premodern Sanskrit learning tout court. ${ }^{5}$ Quite a number of innovative literary works were produced there in this period, moreover; and some among the Śaiva authors in question actively participated in this cultural and literary tradition by composing texts that contributed to selected non-tantric literary genres. A study of these authors thus opens a window into the ways in which religion functioned in larger intellectual and public spheres in a period of tremendous intellectual and cultural flourishing, even if the present essay will examine the internal logic of the selected tradition's philosophical and

(5) Finally, one cannot discount the significance of the location itself: Kashmir was — and is - considered to be one of the most beautiful places of the entire sub-continent, and people simply wanted to live there. This in part explains the long history of Brahminical migration (at the king's invitation) to the Valley from across the sub-continent.

5 The Kashmiri contributions are of course numerous and cover the gamut of fields of Sanskritic learning, from Dharmaśāstra to philosophical writings to vyākaraṇa and other technical literatures, to works of belles lettres in a range of genres, and, of particular note, to the alamkāraśästra. Consider the following. Two of the five works that are demonstrably based on Guṇādhya's Bṛhatkathā were composed in Kashmir (these are the Brhatkathāmañjarī of Kșemendra and Somadeva's famed Kathāsaritsāgara). Virtually all the ālaṃkārikas of the mature phase of the study of aesthetics were Kashmiri—including Vāmana, Bhațta Udbhața, Rudrața, Ānandavardhana, Bhațta Nāyaka, Kuntaka, Mukulabhațta, Mammața, Ruyyaka, and Pratīhārendurāja. In the various areas of Śāstric learning, the famed Naiyāyika Bhațta Jayanta was Kashmiri, as were Varadarāja and possibly Vyomaśiva. Among the Buddhists, Arcața, Dharmottara, Śankkaranandana, and Jñānaśrīmitra hailed from the Valley, and Vinītadeva (among many others) spent time there. The grammarians Jayāditya and Vāmana, authors of the Käśikārrtti, are thought by some to have been Kashmiris, and Kaiyața certainly was (and is said to have been the son of Mammața). So, too, was Helārāja a Kashmiri (of course he is the author of the Prakīnnaprakāśa commentary on the Vākyapadīya). Medhātithi, the famed early commentator on the Mānavadharmaśāstra, also hailed from the Valley, as, of course, did Kalhana, the author of the Räjataranginī.

Additionally, a number of key works of unnamed authorship can be shown to have Kashmiri origins, including the Viṣnudharmottarapurāna, the Haracaritacintāmaṇi, and the Mokșopāya, which, as by now is well known, is the early recension of the Yogavāsiștha. Among Śaiva scriptural works, we can say with some confidence that the Brhatkālottara, the second, third, and fourth șatkas of the Jayadrathayāmalatantra, the Svacchandatantra, the Netratantra, and, in all probability, the Tridaśadāmaratantra (about which I wrote my M.Phil. thesis at Oxford under the direction of Alexis Sanderson, the product of which may be found in evidence in Nemec 2013) are Kashmiri productions. Among Pāñcarātrika scriptures (this according to Alexis Sanderson), the Jayākhya-, Jayottara-, and Sāsvata-samhitās are of a Kashmiri provenance. Finally, I note that many other works were also influential in the Valley, and were heavily studied there, even if they cannot be proven to have a Kashmiri provenance. For a survey of Kashmiri authors and the scholarship that treats them, see Nemec 2015. (I thank Harunaga Isaacson for his contribution to my understanding of the provenance of these anonymous tantric works, which came in the form of personal correspondence, via email, in December of 2013.) 
religious writings rather than explain the relationship between such writings and those of other, more "secular" genres.

The wider cultural context of the Kashmir Valley is of note, because scholars have sometimes linked the purportedly transcendent nature of religious authority - and of textual production more generally - to a concomitant, forced stasis in the social order. Rigid and purportedly timeless ideas about the nature of reality and the place of various peoples situated in it, the thinking goes, produced and supported rigid rules concerning the innate rights and capacities of particular individuals and groups, with such rights and capacities inevitably being hierarchically and inequitably defined, all in a manner as resistant to change as the transcendent sources of religiously sanctioned authority were held to be. The precise social implications of a religious worldview that welcomes innovation, in a context in which innovation in literary production was not uncommon, is therefore of primary concern in defining the role of religion in public life in premodern South Asia. ${ }^{6}$

In what follows I will proceed in three stages. First, I will offer a précis of the problematic associated with the issues to hand, this by examining Pollock's theorization of the relationship of theory (śāstra) to practice (or prayoga) in premodern South Asia. Pollock is selected for further examination because his writings on premodern South Asian cultural change are, in my view, the most sophisticated and engaging of any scholarly treatment of the subject to date, even if I will ultimately adopt his view only in part, challenging it in part as well.

Following this, I will examine key textual passages from the writings of the tradition here placed under study, this to illustrate the ways in which transcendentally authorized religious ideas can be conceived simultaneously to be historically situated and, indeed, new - and therefore demanding of a new social consciousness. Here I wish to support the claim that social change in premodern South Asia tends almost invariably to be incremental, not revolutionary, in nature. It regularly — not to say exclusively—involves modifications of social norms and strictures, not wholesale changes thereof. The relevant textual passages will be examined in two sections, the first dealing with the tradition's emic theory of textual authority, the second with its religious practices.

6 The idea, then, is to begin, at least, to consider the tantric Śaivas' religion in light of the existence of their non-tantric lives (if not explicitly their non-tantric textual contributions), as well to measure their religious writings with the wider social, cultural, and intellectual contexts in which they thrived in mind. I intend, anyhow, to make a start at this here by examining the role of innovation, of change, in religion, even if any exploration of these themes more broadly will have to wait for a subsequent study. 
Finally, I will conclude by charting the implications of this exemplar in a concentric series of contexts, culminating with the study of religion, broadly conceived. If I might be allowed to argue by way of example-ab uno disce omnes - I will suggest in conclusion that the present illustration offers insight into the nature and functioning not only of religion in premodern India, but also of religion tout court.

The issues associated with endeavors to negotiate cultural and social change may be set in the brightest relief if we read them in light of what is in my view the most sophisticated treatment to date of the relation of śästra-i.e., (textual) theory - on the one hand, and cultural and intellectual practice or prayoga, on the other, that of Sheldon Pollock (as articulated in a pair of articles: "Mīmāṃsā and the Problem of History in Traditional India" [1989] and, perhaps more importantly, "The Theory of Practice and the Practice of Theory in Indian Intellectual History" [1985]). Pollock has argued, in what is the most significant theoretical contribution of this pair of articles, that classical Sanskrit theoretical works in premodern South Asia articulated an epistemological formulation according to which there was no dialectical relationship between theory (śästra) and practice (prayoga). New practices were not seen as able to challenge or shape theoretical models, Pollock has argued, due to the claimed $a$ priori status of the theoretical works themselves, which came to be understood to represent (in, he suggests, the language of Ryle) a form of "knowing that" a given social or cultural form was in its very nature just as it appeared in practice, as opposed merely to offering a "knowing how" the social or cultural form in question functioned or could function (based on empirical observation). ${ }^{7}$

This is to say that the purportedly timeless and authorless works defined the world in terms of what it is and should — and must - be, rather than articulating a contingent theory, one subject to revision on the basis of on-theground practices, or in other words in a dialectical relationship with events. "For here," Pollock argues, "on a scale probably unparalleled in the pre-modern world, we find a thorough transformation-adopting now Geertz's well-known dichotomy—of 'models of' human activity into 'models for,' whereby texts that initially had shaped themselves to reality so as to make it 'graspable,' end by

7 See Pollock 1985, 504 . 
asserting the authority to shape reality to themselves." ${ }^{8}$ Pollock ultimately identifies three consequences to this theory of theory and its practical application: (1) the "'creation' of knowledge" was understood to be exclusively a divine activity; (2) knowledge was "by and large viewed as permanently fixed in its dimensions"; and (3) third and finally, there could be "no conception of progress, of the forward 'movement from worse to better,' on the basis of innovations in practice." ${ }^{\prime \prime}$

One product of such "ahistoricality"10 was an apparent stasis in Brahminical views of the normative social order, at least as such views were codified in the classical Sanskrit śāstras par excellence - the Vedas, which, to reiterate, were reified as authorless and timeless works and said therefore to convey transcendent and unchanging truths. ${ }^{11}$ The śāstras were self-consciously understood to

8 ibid.

9 See Pollock 1985, 515.

10 This is the term so often used to describe Indian attitudes toward history—and change. Pollock is not alone in using it (though one should be careful to note that he deploys it differently, and in a markedly more self-conscious and sensitive manner, than his predecessors). So much was it perceived to be the case that India knew nothing of history, that some Western Indologists around the turn of the last century went so far as to suggest, per A.A. MacDonell, for example, that "early India wrote no history because it never made any." See MacDonell [19oo] 1962, 8-9; cf. footnote 1, above; finally, see footnotes 11 and 27, below, for Pollock's use of the term in question.

11 As Pollock $(1989,606)$ understands it, the practice of producing "a content invariably marked by ahistoricality" has its root in the early history of Vedic exegesis, which sought to establish the authority of the Vedas by claiming them to be timeless and authorless productions-ahistorical productions - in which any apparent references to contemporaneous events or persons were said to be explicable by a variety of analyses that served to vitiate any reference to historical realities. See Pollock 1989, 6o8:

Mīmāmsā holds on empirical grounds that the tradition of the recitation of the Vedas must be beginningless (uktam tu śabdapūrvatvam, PMS 1.1.29; cf. Ślokavārttika, Vākyādhikarana, vs. 366). But that is not sufficient to prove its transcendence and thus infallibility (something false can be beginningless, the jātyandhaparamparānyāya). It is therefore argued that the Vedas are transcendent by reason of their anonymity. Had they been composed by men, albeit long ago, there is no reason why the memory of these composers should not have been preserved to us. Those men who are named in association with particular recensions, books, hymns of the Vedas-Kathaka, for example, or Paippalādaka - are not to be regarded as the authors but simply as scholars specializing in the transmission or exposition of the texts in question (a khyya pravacanāt, 1.1.3o; pürvapakșa ad 1.1.27). Texts for which no authors can be identified have no authors, and this applies to the Vedas and to the Vedas alone (which are thus presumably the only authentically anonymous texts in Indian cultural history).

See also ibid.:

The transcendent character of the Vedas, which is proved by the fact of their having no beginning in time and no author, is confirmed by their contents: the Vedas show 
articulate a range of social and other normative views that were consciously held to be unassailable, because the works in which they were recorded were said to stand entirely outside the realm of mundane and contingent existence:

History, one might thus conclude, is not simply absent from or unknown to Sanskritic India; rather it is denied in favor of a model of 'truth' that accorded history no epistemological value or social significance. The denial of history, for its part, raises an entirely new set of questions. To answer these we would want to explore the complex ideological formation of traditional Indian society that privileges system over process- the structure of the social order over the creative role of man in history - and that, by denying the historical transformations of the past, deny them for the future and thus serve to naturalize the present and its asymmetrical relations of power. ${ }^{12}$

no dimension whatever of historical referentiality. Allusions to historical persons or to historical sequentiality are only apparently so. For instance, the Vedic sentence 'Babara Prāvāhaṇi [son of Pravāha] once desired ...' [Ts 7.1.5.4]—which might establish a terminus post quem for the composition of the text (i.e., after Pravāha begot Babara) contains merely phonemic resemblances to the names of historical persons (param tu śrutisāmānyamātram 1.1.31; pūrvapakṣa ad 1.1.28). 'Etymological' analysis shows that the references are in fact to eternally existing entities (in the case in question, to the 'howling wind').

Note that Pollock thus challenges the notion, maintained by earlier Indologists such as MacDonell, that such ahistoricality reflects any lack or deficiency in Indian intellectual historical awareness, and he clearly would disagree, as I emphatically do, with those earlier Indologists who denigrated Indian thinkers for failing to develop a "proper" (Western-like) historical consciousness. See, e.g., Pollock 1989, 604: "I believe the received view about Indian historical consciousness is constructed out of a set of ideas whose truth can no longer be taken for granted: ideas about history and narrativity as such, about ancient historiography in general and Indian intellectual history in particular. Moreover, even if we grant that there are idiosyncratic features about the traditional Indian response to historical experience, the characteristics of this idiosyncrasy have never been adequately described or convincingly explained." (See also, ibid.: "On the face of it the reduction of historical consciousness to a 'zero-category' for traditional India is improbable; from the viewpoint of phenomenology, which offers us the most sustained analysis of such consciousness, it is impossible.") Rather, Pollock argues, any "ahistoricality" is intentionally constructed, in his view to perpetuate the social control of those (Brahmins) who constructed it. See below. 
If I question Pollock's model in part, it is not because it is nowhere operative in premodern South Asia or, mutatis mutandis, in contemporary Indian religions. For, decidedly it was, and sometimes is; and Pollock's theory adroitly explains a strategy for dealing with cultural and social change that in its primary features is also operative in other religious traditions of other times and places. Indeed, it signals what is a fundamental concern for religion and does much to theorize and explain what is a common response to it. ${ }^{13}$ Where I differ with Pollock is with his understanding of this model as monolithic, as functioning equally across the gamut of premodern śāstric modes of discourse and across textual genres and religious traditions. ${ }^{14}$ For the facts as we can discern them "on the ground" in the period in question challenge the universal applicability of his model, and the construction and use of religious authority in premodern South Asia was regularly if not uniformly more complex than Pollock's model allows.

Two dimensions of textual production in premodern South Asia complicate his view of the śāstras - the normative, technical, and for our purposes religious writings - of classical India. These are, firstly, (1) the fact that the canon - or, more precisely, canons - of Hindu scripture remained (and in certain instances continue to remain) open, allowing for a proliferation of scriptural sources regularly to emerge "on the ground"; and, secondly, (2) the fact that "ahistoricality" - the very basis of the authorless and timeless transcendence that, Pollock has shown, furnished (religious) authority-was conceived in multiple ways, including, in the tradition placed under consideration in this essay, in a manner that allowed purportedly divine and timeless teachings simultaneously to be associated with the particular biographies of historicallylocated religious figures ("perfected ones" or Siddhas, in the present example).

13 The concern may be summed up in plain terms, namely, that while the world changes, the religious ideas, ideals, practices, and principles that are meant to shape and guide human activity are established before such changes can be known or fully anticipated. More than this, religious authority not infrequently is derived from its very antiquity, from the fact that it is born from what is said to be a transcendent source or sources, which can speak "truths" neither produced by, nor subject to the revisions of, the fallible and fickle. There is a need, then, to prove the prescience of the religiously authoritative sources, either through exegesis or eisegesis: one may do so either by finding events as they eventually transpired to have been anticipated in the scriptures or by reading events as they transpire into the scriptures themselves.

14 On the ubiquity of this strategy, in Pollock's view, see footnote 27, where he refers to the use of the strategy in "whatever sort of [Sanskrit] text it might be" that one has to hand. 
This pair of dimensions of scriptural production allowed for the recognition of and advocacy for change in Hinduism in ways that have heretofore passed without mention: religious authority could be conceived of as simultaneously new and timeless; and in a context in which religions could readily proliferate textual sources of a staggering variety, religious authority was complex, both because it was layered and because it could and did change over time. It is precisely for these reasons that the example offered by the Śaiva tantrics of Kashmir both challenges and confirms elements of Pollock's theory.

I begin the case-study with the examination of a theoretical work, a śästra, one inspired by Śaiva tantric scriptures and views, but one voided of explicit references to such texts: Utpaladeva's Íśvarapratyabhijñākärikās (hereafter ĪPK), the preeminent expression of Pratyabhijña philosophy, for which the author wrote both a short and a long autocommentary, respectively the Ísvarapratya-

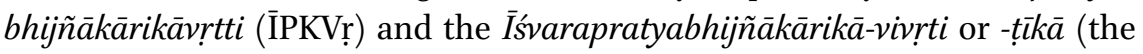
latter of which is lost excepting that a number of fragments of the work have been recovered in recent years; see chapter 5 of this volume). The İPK and İPKVr offer an exoteric explanation for the nature of the divine and the place of the practitioner in the world. They were written by a Brahmin who in his public life would have adhered to caste norms and the associated rules of purity and pollution. Yet, as is well known, Utpaladeva and the other authors of the Pratyabhijñā simultaneously would have allowed, in theory, at least, for the contravention of these rules in the context of the family of tantric initiates, a complex practice summarized by the famous dictum, "internally a Kaula, externally a Śaiva, and in social practice a follower of the Veda." ${ }^{15}$ (I will return to this maxim in what follows in order to examine the wider textual context in which it is recorded.)

My contention is that the $\overline{\mathrm{I}} \mathrm{PK}$ and its commentarial tradition exemplify the possibility of self-consciously introducing religiously_indeed, what are held to be transcendently - authorized innovations, and that they also serve to illustrate and explain the possibilities and limits of such innovations on contemporaneous social life. Consider, to begin, the by now well-known invocatory verse (mangala) of Utpaladeva's masterwork:

15 See TĀV ad TĀ 4.251ab (vol. 3, p. 278, line 5): antah kaulo bahiḥ śaivo lokācāre tu vaidikah. Cf. TĀV ad TĀ 4.24cd-25ab (vol. 3, p. 27, line 11).

I note that there is a difference in the writings of Utpaladeva, Somānanda, and Abhinavagupta as regards the place of the norms of varnāśramadharma; for, the latter two authors were more explicit in their understanding of the merely conventional nature of such social distinctions than was Utpaladeva (in the ĪPK and ĪPKVṛ, at least). 
Having somehow become a servant of Maheśvara, wishing to offer assistance to all people (janasyāpi), I will facilitate the recognition of [the Lord], which brings about the achievement of all successes. ${ }^{16}$

Utpaladeva's stated wish to assist "all people" (janasyāpi) requires further examination, and I will return to this statement in what follows. More immediately, one may note two key and perhaps obvious qualities of the mangala as it is offered to the reader. First, Utpaladeva claims access to the transcendent, for he says he has "somehow become a servant of Maheśvara," i.e., of Śiva. Second, he promises to bring others to a similar level of accomplishment by accounting for his insight in the very text that is to hand, paving a path for others to the same ennobled state.

The first quality is anticipated in the mañgala with which Somānanda opens his Śivadrșți (hereafter ŚD), a verse that is also by now well known:

May Śiva, who has penetrated/possessed my form by warding himself off by means of his own self, pay homage to his (all-)extensive self by means of his own power. ${ }^{17}$

Here, as before, the author's association with Śiva is noted, though it is rather more prominently asseverated than is the association with Śiva described by Utpala in the İPK-for the śD uses the Kaula scriptural idiom of possession. We thus clearly are not met with those who count themselves merely to be informed intellectuals, but with those who claim to be both scholars and practitioners, who understand themselves to be close to- or in fact the very embodiment of-God in the form of Siva.

So much is confirmed in the history of the transmission of the teachings of the Pratyabhijña that is found in a textual passage appended to the Sivadrșți, said to be an autobiographical account of Utpaladeva's teacher, Somānanda. ${ }^{18}$

16 See ĪPK 1.1.1: Kathañcid āsādya maheśvarasya dāsyam janasyāpy upakāram icchan | samastasampatsamavāptihetum tatpratyabhijñām upapādayāmi.

17 See śD 1.1: asmadrūpasamāviștạ̣ svātmanātmanivāraṇe | śivaḥ karotu nijayā namaḥ śaktyā tatätmane.

18 An edition and translation of this "autobiography" may be found in Nemec 2011, 22-24. As noted there, I have my doubts about the authenticity of the passage as autobiography, and rather think it is something probably composed after Somānanda's day, but I here note that it is likely to have existed by the eleventh century, as it is replicated, to a substantial degree, in Abhinavagupta's Íśvarapratyabhijñāvivrtivimarśinī (īPVV), which explicitly associates the narrative with the śd itself. (See below, especially footnote 33.) 
While this quasi-mythological passage claims a divine origin for the Pratyabhijñā, origins that were shrouded with secrecy, it emphasizes the emergent quality of the teachings - their very entry from obscurity into circulation among men, or, in a word, their novelty. For the teachings, we are told therein, ${ }^{19}$ were kept by "great-souled sages" (mahātmanām rșinām) until they retreated from the world at the dawn of the Kali Yuga, at which point it was incumbent on God (deva) himself to cross down to earth "in order to grace [humanity]" (devah ... anugrahāyāvatīrnah ... bhütale). ${ }^{20}$ This he did by instructing the irascible and imprecating sage Durvāsas to perpetuate the lineage of initiates. Durvāsas is said to do so by producing a mind-born son named Tryambakāditya, who stands at the head of a fifteen-generation lineage of such mind-born Siddhas (all named Tryambaka). ${ }^{21}$ The last falls in love with a Brahmin woman who bears him a son named Samgamāditya. He in turn is said to have moved to Kashmir, ${ }^{22}$ and over the course of the generations the lineage and its esoteric teachings were passed down to Somānanda. Thus, we are told, the teachings were not lost (nocchidyate).

I would further suggest that the type of autobiographical expression offered by Somānanda is also found in Abhinavagupta's famed autograph verse, with which he opens virtually all his Trika commentarial works and which Sanderson has examined, already, in detail. Sanderson $(2005,89)$ has rendered this bivalent (śleșa) maingala verse as follows:

May my heart shine forth, embodying the bliss of the ultimate, [for it is] \{one with the state of absolute potential made manifest in the fusion of these two, the 'Mother' grounded in pure representation, radiant in ever new genesis, and the 'Father', all-enfolding [Bhairava], who maintains the light [of consciousness] through his five faces\} / \{ formed from the emissions produced through the fusion of these two, my mother Vimalä, whose

References to verse numbers of this "autobiography" reflect the enumeration of the edition found in Nemec 2011.

19 See the "autobiography" at ŚD 7.107a-c. śaivādīni rahasyāni pūrvam āsan mahātmanām | rșināị vaktrakuhare ...

20 See the "autobiography" at śD 7.108-109: kalau pravrtte yāteșu teșu durgamagocaram | kalāpigrāmapramukham ucchinne śivaśāsane. kailāsādau bhraman devo mūrtyā śrīkaṇtharūpayā | anugrahāyāvatīrnaś codayām āsa bhūtale.

21 See the "autobiography" at ŚD 7.111: tataḥ sa bhagavān devād ādeśam prāpya yatnatah | sasarja mānasam putram tryambakādityanāmakam. See also the "autobiography" at ŚD 7.114: siddhas tadvat sutotpattyā siddhā evam caturdaśa | yāvat pañcadaśaḥ putraḥ sarvaśāstraviśāradah.

22 The move to Kashmir is recounted in the narrative at śD $7.118 \mathrm{~cd}$. 
greatest joy was in my birth, and my father [Nara] simhagupta, [when both were] all-embracing [in their union]\}. ${ }^{23}$

These expressions, in turn, reflect the tradition of the poet's autograph verse, which, it must be added, is something of a late phenomenon in the history of Indian literature. I offer for comparative purposes one example thereof, that of Ratnākara (as rendered by David Smith), which opens his famed Haravijaya:

Ratnākara, son of Amṛtabhānu who was the son of him who lived at Gañgāhrada on Himādri's peak and was of Śrīdurgadatta's lineage, wrote this poem, a lovely composition, which is beautiful because it is based on the deeds of Śiva, whose crest is the digit of the moon. ${ }^{24}$

The similarities lie precisely in the fact that by identifying his parentage and/or family lineage each author stakes a claim to his unique biography and thereby his historicality, even if each does so without explicitly situating himself historically with any traceable reference to a calendrical date or reign of any particular royal sovereign. The autograph, then, furnishes precisely what this term suggests, a marker of the unique identity of the author. ${ }^{25}$

23 The verse reads as follows: vimalakalāśrayābhinavasțțtimahā jananī bharitatanuś ca pañcamukhaguptarucir janakaḥ | tadubhayayāmalasphuritabhāvavisargamayạ̣ hrdayam anuttarāmṛtakulam mama saṃsphuratāt. See Sanderson 2005, 89 .

24 The verse reads as follows: śrīdurgadattanijavaṃśahimādrisānugañgāhradāśrayasuta- mrtabhānusūnuh | ratnākaro lalitabandham idaṃ vyadhatta candrārdhacūlacaritāśrayacāru kāryam. See Smith 1985, 104.

25 One may observe that only authors of particular genres reveal much of anything of themselves: some authors never compose autograph verses, or anything similar to them. Thus, while the poets who clearly worked in the royal courts of Kashmir reveal parts of their own biographies to the reader, or at the least are willing to acknowledge themselves as biographical figures, we conversely know little from the playwrights of their parentage or their place in the world, nor do the philosophers reveal much of themselves (though Kalhana places many such figures in history in his Rājatarainginī $)$.

It is clear that the Śaivas of concern in this essay were willing to think of and talk about themselves in a language that best pairs-at least up until the time when they lived - with the literary agents who operated in the "secular" arena of the royal court. In Somānanda's case, his personal story is, as we have seen, offered in semi-mythological terms; Utpaladeva's is presented in the mangala of a text that he surely would have had circulated in intellectual circles, probably those connected, in some significant ways, to the royal court. All of this clearly signals some sense of-some self-conscious awareness and articulation of-historical location, which is proximate to a self-conscious awareness and articulation of novelty. Abhinavagupta's autograph verse in particular is, in my view, most like those of the poets, and it certainly indicates his very entrance into historicality, however extraordinary and exulted he wished to suggest his entrance may have been. 
It bears reiterating that the historical accuracy of such accounts is not here pertinent; what is of concern in these and other similar expressions is the fact that their authors conceive of themselves not only in terms of their historicality, the mere fact that they appear in time, but also in terms of their historicity: ${ }^{26}$ the authors in question claim for themselves - and whatever (religious) authority they claim - the possibility of being mapped historically, located in particular social, political, religious, and other contexts due to their own distinguishable personages and individual biographies.

Most significant is the fact that Utpaladeva is explicit in the IPK about the nature and significance of the spiritual path he describes: it is not only efficient and effective, but it is explicitly new. ${ }^{27}$ This Utpaladeva tells us in the concluding passage of the fourth and final section (adhikära) of the work, where, reflecting on his completed text, he says:

26 I here adopt the distinction between historicality and historicity as defined by J.N. Mohanty (2010, 334): "Historicality is the property of being in history. Historicity is the condition of the possibility of history. One can distinguish between three levels of historicity: historicity of human existence; historicity of a culture; and historicity of scientific thinking and, in the long run, philosophy. A mere fact or an event does not have historicity. Only an ideal meaning, as Derrida insists in his work on Husserl, can have it."

27 That this is so is significant, for it is indeed the case that such expressions of novelty are relatively scarce in premodern Sanskrit sources, as Pollock has noted. But they are not entirely absent, and one suspects that scholars will find a greater number of such passages as they continue to look for them. See Pollock 1989, 6o6: "To an astonishing degree Sanskrit texts are anonymous or pseudonymous, or might just as well be. The strategy of eliminating from the text-whatever sort of text it might be - the personality of the author and anything else that could help us situate the text in time is a formal correlate of a content invariably marked by ahistoricality. Works on statecraft, for example, describe their subject without specific reference to a single historically existing state. Books on law expatiate on such crucial questions as the relationship between local practices and general codes of conduct without adducing any particularized events or cases. Belles-lettres seem virtually without date or place, or indeed, author. Literary criticism prior to the tenth century (Ānandavardhana) neither mentions the name nor cites the work of any poet, the ālaṃkārikas themselves supplying all examples. Philosophical disputation takes place without the oppositional interlocutor ever being named and doxographies make no attempt to ascribe the religious-philosophical doctrines they review to anyone, unless a mythological personage. Even in those texts whose historical vision I suggest merits particular reconsideration-Raghuvaṃśa, for instance-referentiality remains somehow unanchored:We are indeed told that it is the Bengalis that Raghu uproots (4.36), the Kalingas he attacks (38), the Pandyas he scorches (49), the hair of the Kerala women upon which he sprinkles the dust of his army (54), and so on, but if the digvijaya has local contours, it remains essentially timeless. In short, we can read thousands of pages of Sanskrit on any imaginable subject and not encounter a single passing reference to a historical person, place, or event—or at least to any that, historically speaking, matters." 
Thus I have set forth this new (nava), easy path as it was explained by my distinguished teacher [Somānanda] in the śāstra, [entitled] the Śivadrști. ${ }^{28}$

We see this sentiment reiterated, moreover, in the İPKVr, where Utpaladeva glosses the term "new" (nava) with the synonym abhinava; ${ }^{29}$ and Abhinavagupta reproduces this latter term in the shorter of his two sub-commentaries, the İśvarapratyabhijñãvimarśini ( $\overline{\mathrm{I}} \mathrm{PV})$, where he adds that the path in question is both "included in" all the various secret śāstras (sarvarahasyaśāstrāntargata) and, because it has been concealed from public view, is not well known (sannigū hhatvād aprasiddha) ${ }^{30}$

Isabelle Ratié, the first scholar explicitly to note the significance of this passage, has suggested that Utpaladeva refers to the novelty of the path he described in the IIPK because he wishes to indicate that it does not authenticate itself by any overt appeal to scripture..$^{31}$ Now, it is undoubtedly the case that the Kārikās are unmistakably philosophical in tone and content, and that they require no special or extensive knowledge of esoteric scriptural sources for their comprehension; and one may note that Utpaladeva's teacher, Somānanda, similarly obscured the scriptural influences on his articulation of the Pratyabhijñā. $^{32}$

28 See ĪPK 4.16ab: iti prakațito mayā sughața eșa mārgo navo mahāgurubhir ucyate sma śivadrsțiśáastre yathā $\mid$.

29 See İPKVṛ ad ĪPK 4.16: so 'yam avakra evābhinavo mārgah sākșātkrtaparameśvarabhațțārakākārair bhațtaśris̄omānandapādaị śivadrșțināmni prakaraṇe nirdișțo mayā yuktinibandhanena hṛdayamgamīkrtaḥ. etatparisillanena śivatāveśāt jīvann eva mukto bhavati. "This new, direct path was foretold in the treatise entitled the Śivadrști by the venerable Somānanda, whose very appearance is that of the great lord Parameśvara in front of one's eyes; I have made it [i.e., this path] enter the heart(s) (of men) by furnishing a logical justification for it. By pursuing this [path] one becomes liberated in this very life [jivann eva], this as a result of being (fully) penetrated by Siva-nature."

$30 \quad$ See ĪPV ad ĪPK 4.16: asmatparasmeșțhibhațtāaakaśrīsomānandapādaị śivadrșțiśāstre 'yam abhinavah sarvarahasyaśāstrāntargatah sannigüḍatvād aprasiddho bāhyāntaracaryāprānāyāmādikleśaprayāsakalāvirahāt sughațas tāvad uktaḥ ... "This new, easy [path] - (easy) because it lacks in the (need for) skill in the external and internal exertions (usually required) for the (removal of one's) afflictions, [practices] such as appropriate conduct $[$ carya $\bar{a}]$ and breath exercises [ prānāayama]—which is included in all the secret śāstras, (and) is not well known since it has been concealed from public view, was first explained in the śāstra (entitled) the Śivadrșți by the venerable Somānanda, our greatgrand guru."

31 See Ratié 2011, 6 (and especially note 8): "Pourtant, Utpaladeva lui-même présente la Pratyabhijñā comme une 'voie nouvelle' (mārgo navaḥ). Nouvelle, elle l' est avant tout au sens où elle ne fait pas appel à l' autorité scripturaire."

About this phenomenon, see Nemec 2011, 12-19. 
I would propose, however, that one must understand a rather different justification for Utpaladeva's description of the path he describes as "new." It is not—or, rather, it is not merely — the fact that one need not appeal to Śaiva scriptures to follow it; rather, I suggest that the primary sense of Utpaladeva's description of the path as "new" is that it is new to humanity. As is evinced in Somānanda's "autobiography," the Pratyabhijñā teachings were said to have been concealed by great sages at the beginning of the Kali Age, preserved as they were by means of the secret lineage described therein, and were only revealed subsequently for the benefit of those who would come to be initiated into its ways. Some justification for linking these mythological origins to the attested novelty of the path may be found, moreover, in the fact that Abhinavagupta explicitly invokes the narrative found in Somānanda's "autobiography" in a passage of the İPVV that comments on İPK 4.16, precisely the verse in which the novelty of the Pratyabhijñāss path is proclaimed. And in doing so Abhinavagupta may be understood himself to associate the lineage with Utpaladeva's claim to novelty. ${ }^{33}$

The Pratyabhijñā thus presents the reader with a self-conscious (theoretical) understanding of their śästra as divinely sanctioned, guaranteed by the identity of the authors in the lineage with Siva himself; and, while thus divinely sanctioned, the śästras are intimately, inextricably, tied to the biographies of individual, monadic agents-Utpaladeva, Somānanda, and those preceding and following them in their lineage. Thus, and perhaps not unlike the theology

33 ĪPVV ad ĪPK 4.16 (vol. 3, p. 402, lines 14-20): śivadrșțīti tadgatam ā śrīkanțthanāthāt guruparvakramam sūcayati. tatra hi śrísirikaṇthanāthah śāsane samutsanne śrīdurvāsomunị̣ tadavatārañāya dideśa, so 'pi śrītryambakādityam traiyambakākhye lokaprasiddhyā tairimbābhidhāne gurusantāne pravartayitāram mānasaṃ sasarja-ityādi vitatyoktam. śrīkaṇțhanāthaś cādhigatatattvah śrimadanantanāthāt, so 'pi śrībhagavacchaktita ityādy āgameșu nirūpitam iti sampūrṇo guruparvakrama uktah.

Compare, in the following graph, the lineages as articulated in the ĪPVV and the ŚD "Autobiography," with coincident names in the respective lineages underlined: IPVV: Bhagavacchakti $\rightarrow$ Anantanātha $\rightarrow$ Śrikkaṇțhanātha $\rightarrow$ Durvāsas $\rightarrow$ Tryambakāditya.

ŚD "Autobiography": Śrīkaṇṭha $\rightarrow$ Durvāsas $\rightarrow$ Tryambakāditya $\rightarrow 14$ Tryambaka-s $\rightarrow$ Saṃgamāditya $\rightarrow$ Varșāditya $\rightarrow$ Aruṇāditya $\rightarrow$ Ānanda $\rightarrow$ Somānanda.

Clearly, Abhinavagupta wishes both partially to confirm the lineage offered in the "autobiography" and also to add to it at the top the persons Bhagavacchakti and Anantanātha. (Or, if the composition of the śD "autobiography" postdates that of the İPVV, one may instead conjecture that the author of the former wished to add to the lineage of the latter at the tail end of the same.) 
associated with, e.g., the avatära theory, we are here offered a view of Siddhas or "Perfected Ones" who have emerged in human form in the world in their particular historical contexts, contexts to which they could — and did—actively and explicitly respond. Finally, this concurrence of historicity and divine authority allows the $\overline{\mathrm{I}} \mathrm{PK}$ in particular to claim to offer something that is plainly and explicitly "new" (nava), yet nevertheless "transcendent," even "timeless," as it were, insofar as authorized by Śiva himself. The Pratyabhijñā thus achieves in its explicit and implicit theoretical formulations the apparently paradoxical aims of offering something both historically located and new, on the one hand, and transcendent, on the other, the teachings being ultimately authored and authorized by Śiva himself and thus held to be uncontained by any historical bounds.

\section{The Kashmiri, Śaiva Example in Practice}

This much, then, represents the Kashmiri non-dual Śaivas' theory, their selfconscious view of the place of their śästra and those who carry it in history. But, what of their practices? What did their theory suggest they should do, and what, so far as can be known, did they do?

As is well known, the Śaivas of the Pratyabhijñā understood the various practices related to varna or birth to involve mere social custom, their view being that caste identity was not based in any real difference in the natures of the individuals so marked by it. We see this view exemplified perhaps nowhere more clearly than in a passage of Somānanda's śD (at 3.42cd-47), where the question of the need to purify a fire installed in an outcaste's, a canḍāla's, ${ }^{34}$ house is addressed:

svecchāto bhävarūpatve parādhīnā kutah sthitị kșiravad yadi vocyeta parādhinam jaḍạ bhavet etayaiva diśā śodhyaṃ śuddhanyūnādidūṣanam 3.43 abhagne 'sya svarūpatve śuddhanyūnādikam kutặ patadgrahādike hemni hematvam mukuṭādike 3.44 sthitam eva na hemno 'sya kācid asti vibheditā caṇ̂ālasadmago vahnir na vahnir yadi kathyate $\quad 3.45$ tad evam syād athocyeta vahneh saṃskāracodanā śāstreșu varnitā kasmāt kāryārthaṃ kāryam eva tat 
na svarūpavibhāgo 'tra tathā tatra vyavasthitẹ saṃjñākaraṇamātram tad vyavahārāya kalpitam

Given that he [i.e., Siva] exists of his own volition in the form of (all) the entities (that make up the universe), how is existence dependent on another than himself? If, for example, you say it [i.e., the purported dependence] is one similar to (the example of curds, whose genesis depends on the) milk (of which they are comprised), it [i.e., the universe] would be insentient, dependent on another. The fault (attributed to our system) that must be corrected-being pure, being diminished, or the like-is precisely the result of this (wrong) point of view. How can there be something pure, something diminished, etc., when his nature is undivided? The fact of being gold simply exists in gold, (be it) in (the form of) a golden spittoon, etc., or in (the form of) a tiara, etc. The (fact of being) gold is in no way divided [i.e., differentiated] whatsoever. If you argue that a fire installed in an outcaste's house is not (properly) called a fire [i.e., it is not a proper, ritually-purified fire], we reply: that may be so [i.e., this does not contradict our notion of the uniformity of the nature of fire as such]. But, if you say (in reply) that injunctions involving the rites of passage for fire are explained in the (Śaiva) teachings, (we reply:) what is the goal of the (ritual) action (in question)? It is the action itself. ${ }^{35}$ There is no division of its [i.e., the fire's] nature, here. It is the same for his [i.e., Siva's] abiding there [in the world]: that [i.e., the distinguishing of "pure" from "impure" elements in the world, or the distinction of that which is said to be Śiva and that which is said not to be] is conceived of merely as the assignation of names for the purpose of everyday speech/everyday activity [ryavahāra]. ${ }^{36}$

In other words, there is no substantial change in the fire qua being fire that results from the performance of the ritual. It is a social custom, not something that materially transforms the fire so treated.

36 See also the ŚDVṛ on the same passage: atha vahner yady aśuddhatā na syāt tat tasya kuto mantraị samskārayogah kāryasampādanārtham śāstre codyeta tasmāt tasyāśuddhatā saṃbhavet. naivam kāryam evānuștheyam eva tad vyavahārāya na tu svarūpe vahner vibhāgah, svarūpe nijarūpe sthite tu vahnāv upagamyamāne tatsvarūpatā vahnirūpataiva sarvatra. tadvac chivarūpatājagatas tasya, tatheśvaratanmātraprthivyādirūpatayā vyavasthānāt parasthūlasūkșmatādibhedaḥ. tathā ca sarvatraikye saṃsāravyavahārāya saṃjñäkaranamātram tat kalpitam bhavati. "Now, if you argue that, if fire cannot be impure, then it is inexplicable why the rites of passage, replete with the mantras, are enjoined to it in the (Śaiva) teaching(s), this for the purpose of accomplishing their (purifying) effect; thus, it must be possible that [fire] can be impure, (we reply:) this is not so. The rite itself is simply established for the purpose of everyday speech/activity, while 
That caste distinctions should not disqualify anyone from hearing the teachings of the İPK has also been stated plainly enough, if somewhat obliquely, in the mangala verse of the I PK, where, as noted above, the "new path" (nava märga) is explicitly said to be offered to "all people" (janasyāpi). While the mangala is merely suggestive of any implications regarding caste, however, the ĪPKVṛ and Abhinavagupta's $\bar{I} P V$ and $\bar{I} P V V$ further clarify what is intended by the expression; and what Utpaladeva means by "all people" is explained with increasing clarity as one delves into the succeeding levels of commentary.

The İPKVr indicates that one should understand the term to refer to all people without exception: Utpaladeva glosses janasyāpi with imam akhilam. ${ }^{37}$ Abhinavagupta, in turn, addresses the caste implications of this pledge- to help all people-in a more explicit fashion. In the İPV subcommentary, he indicates that the term jana refers to any person regardless of the circumstances of his birth (janasyeti yạ̣ kaścij jāyamānah tasya); and he further specifies that no distinction by the "office" held by a candidate for initiation (adhikārivișaya) may serve to restrict access to the teachings of the Pratyabhijñā. ${ }^{38}$ He later adds that the term in question should be understood to refer to anyone afflicted by the suffering of incessant births and deaths. ${ }^{39}$

Finally, Abhinava also is explicit, in both the İPV and I PVV, in stating that jāti should not be considered an appropriate measure of a candidate's eligibility for entry into the soteriological path of the Pratyabhijñā. This he does in the passages of his two sub-commentaries that address the concluding verse of the Kärikās, where Utpaladeva has again indicated that the text is meant for "[all] people." Referring to himself in the third person, he says (at İPK 4.18):40

there is no change in the nature of the fire. Rather, it being established that fire is fixed in its nature, i.e., in its own form, the fact of having that nature, i.e., the very fact of being fire, exists in every instance (of fire). Similarly, the universe has Siva as its nature. Thus, division into the fact of being supreme, coarse, and subtle, etc., exists as a result of (the same Siva) being established in the form of the Lord, the subtle elements, the earth, etc. And thus, there being oneness everywhere, that [i.e., such categorization or division of Śivanature] is conceived of as merely the assignation of names for the purpose of everyday speech/everyday activity in samsāra."

37 See ĪPKṾ̣ ad ĪPK 1.1.1. parameśvaraprasādād eva labdhātyantadurlabhataddāsyalakșmīr aham ekākisaṃpadā lajjamāno janam apimam akhilaṃ svasvāminam vakșyamāṇopāyena pratyabhijñāpayāmi yena tasyāpi paramārthalābhena paritușyeyam.

38 See ĪPV ad İPK 1.1.1. (vol. 1, p. 14, lines 10-12): janasyeti yaḥ kaścij jāyamānaḥ tasya, ity anenādhikārivișayo nātra kaścin niyama iti darśayati ...

39 See İ PV ad İ PK 1.1.1. (vol. 1, p. 15, line 9) where Abhinava glosses jana with anavaratajananamaraṇapị̂ita.

40 See ĪPK 4.18: janasyāyatnasiddhyartham udayākarasūnunā| iśvarapratyabhijñeyam utpalenopapāditā. 
In order that [all] people (jana) can attain perfection effortlessly, Utpala, the son of Udayākara, has presented this İśvarapratyabhijña a [treatise].

Abhinava's I PV suggests that with "people" (jana) Utpaladeva refers to any person, for neither jāti nor any other criterion is innately disqualifying. ${ }^{41} \mathrm{He}$ reiterates the same in the İPVV as well, where, additionally, he excludes the individual's "conduct" (ācāra) from consideration in determining whom the teachings may help. ${ }^{42}$ Note also that the ĪPVV explicitly links the present passage with the one found at the beginning of the İ $\mathrm{PK}$, saying: etac ca prārambha evāsmäbhir vitatam..$^{43}$ Simply, distinctions marked by birth-including caste distinctions-are to be ignored.

The professed catholic reach of the work is significant, not only due to its inclusivism, a quality well attested in the context of tantric rules of initiation, even if this cannot be taken to imply the existence in practice "on the ground" of a concomitant equality of participation, or status, within the context of the initiatory "family" (kula); but it is further significant that it is declared, albeit obliquely, in the İPK (and İPKVṛ), a text (and commentary) that has all the hallmarks of works intended for audiences of non-initiates. ${ }^{44}$ I submit that there must have been some appreciation for a certain novelty in the apparent inclusivism professed in the work. This, then, may constitute another reason for Utpaladeva's description of the Pratyabhijñā path as "new": it offers a certain novelty in being (more or less explicitly) indifferent to caste distinctions.

While the use of the term jana in the İPK offers a certain ambiguity of expression, Abhinava's subcommentaries are explicit in stating the inclusivism of the śāstra. One can thus see operative here a certain stratification of expression, a certain obliqueness with regard to any reference to caste in the İPK and IPRV rr, but a more explicit asseveration of the sociological parameters of the tradition in Abhinavagupta's sub-commentaries. So much of course reflects the

41 See ĪPV ad ĪPK 4.18 (vol. 2, p. 276, lines 5-6): yasya kasyacij janor iti nātra jātyādyapekșā kācid iti sarvopakāritvam uktam. See also the avataranikā to ĪPK 4.18 (ĪPV, vol. 2., p. 275, line 14), where Abhinava describes the śāstra in question as one that can help "everyone": sarvopakārakam mahāphalam idạ̣ śāstram ...

See ĪPVV ad ĪPK 4.18 (Vol. 3., p. 404, lines 6-8): yaḥ kaścijjananadharmā, tasyātaḥ siddhị, na tv atra jātyācārāâu bhara iti sarvānugrāhakatvam uktam. etac ca prārambha evāsmābhir vitatam.

43 See footnote 42.

44 On the intended audiences of the ĪPK and ĪPKVṛ, on the one hand, and the śD (and ŚDVṛ), on the other, see Nemec 2011, 12-19. 
complex of practice of the tradition, exemplified as it is by the dictum quoted above, "internally a Kaula, externally a Śaiva, and in social practice a follower of the Veda."

This dictum and the complex practice it invokes-one of engaging different rules and norms in differing contexts-is explicitly tied to the question of social practices, those associated with caste and life-stages, as the context provided by Jayaratha for this quotation clearly indicates. For he considers the significance of preserving the social order-varnāśramācāra-precisely where he quotes the complex form of practice that is here of concern..$^{45}$ Moreover, the entire matter is raised in the context of coming to understand precisely whether the Śaiva practitioner should respect the Veda-based rules of purity and impurity. For the relevant section of the fourth a ahnika of the TĀ is governed

45 See TĀ (and TĀV ad) 4.251ab (vol. 3, p. 277, line 9 to p. 278, line 6): evam sarvotkrșțatvāc chaiva eva śāstre mukhyayā vrtttyā nișthā kāryā, nānyatrety āha tasmān mukhyatayā skanda lokadharmān na cācaret | 4.251ab nișthāśūnyatayā tu gaunyā vrttyā lokasaṃrakṣaṇārthaṃ lokadharmān ācarato na kaścid doṣa iti bhāvah. tad uktam tatra ye tu varnāsóramācārāh prāyaścittāś ca laukikāḥ | saṃbandhān deśadharmāṃśs ca prasiddhān na vicārayet. garbhādhānāditaḥ krtvā yāvad udvāham eva ca | tāvat tu vaidikaṃ karma paścāc chaive hy ananyabhāk. na mukhyavrttyā vai skanda lokadharmān samācaret.

iti. ata eva antah kaulo bahị śaivo lokācāre tu vaidikah | sāram ādāya tiștheta nārikelaphalạ̣ yathā.

"Thus, [Abhinavagupta] says that, since it is superior to all (other śāstras), what is to be done is fixed in its primary sense in the Śaiva śāstra alone and not elsewhere:

'Therefore, O Skanda, one need not observe the rules of the (everyday) world as though they were of primary importance.'

However, the sense (of this passage) in its secondary meaning, absent of what is fixed (to be done), is that no fault accrues to the one who performs lokadharma for the purpose of protecting the people/world [loka]. The following is said on the matter:

'Moreover, one should not cause the well-known, proper customs of the country (in which one lives) to go awry, these being $(y e)$ the societal [ laukikäh] acts of conduct associated with varna and âśrama and the expiatory acts. From the time beginning with the ceremony before conception and until one has performed the wedding ceremony, Vedic acts (are to be enjoined). Following this, one is to be devoted to the Śaiva [path] and no other. Indeed, O Skanda, one need not perform the rules of the (everyday) world as though they were of primary importance.'

For this very reason:

'Internally a Kaula, externally a Śaiva, and in social practice a follower of the Veda, having extracted the essence, one should remain, as does the fruit of the coconut." 
precisely by the question of how the jivanmukta should behave in the world, and Abhinavagupta explicitly cites the eighteenth chapter of the Mãlinìvijayottaratantra there as an authoritative voice in the matter. ${ }^{46}$ Note, in addition,

46 See TĀ 4.213-221ab (vol. 3, pp. 241ff., which quote the Mālinìvijayottaratantra, verses 18.7481):

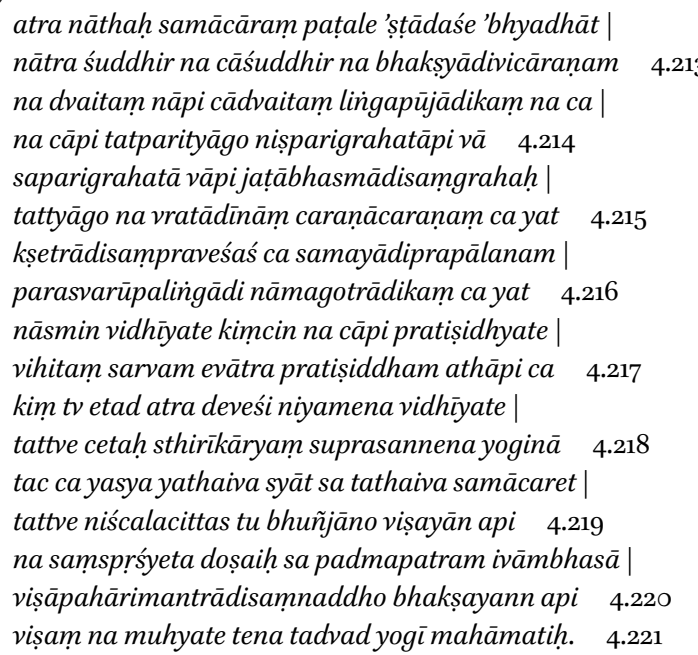

"Here, the Lord has explained the appropriate conduct (of the accomplished yogin) in the 18th chapter (of the Mâlinivijayottaratantra): 'There is no purity here, nor impurity, no consideration of what is to be eaten, etc. There is no duality, nor non-duality, and no (requirement to perform) acts of devotion to the linga, etc. There is similarly no (requisite) abandoning of those [acts], nor the (required) renunciation of material possessions, nor again any (requirement regarding the) accumulation of material possessions. There is no (requisite) maintenance of twisted locks of hair [jața], of (smearing oneself with) sacred ashes, or the like, nor any (requisite) abandoning of the same. And as regards the performance or non-performance of vows, etc., and entrance into sacred places, etc. [i.e., kșetras, pịthas, and upapițhas; see TĀ 4.259cd and the TĀ̃ thereupon], the observance of rules of action, and (those rules associated with) initiatory name, initiatory lineage [gotra], or the like [i.e., according to the lodge (ghara) and the like of the initiate; see TĀ $4.267 \mathrm{~cd}]$, whether the form, sectarian marks, and so on be one's own or another's-nothing is prescribed here regarding these, nor, contrariwise, prohibited. Absolutely everything is performed here [according to the rules of the Mãlinivijayottara], and, contrariwise, omitted. Yet, this (alone) is necessarily enjoined here [in the Mâlinivijayottara], O Goddess, that the wholly pleased yogin must fix his consciousness [cetas] on reality; and he should therefore act only in accordance with that [reality (tattva)], whatever that may be for him. Moreover, the one whose consciousness [citta] is fixed on reality, partaking even in the pleasures of the senses [vișaya], is not touched by bad consequences, just as the petal of a lotus (is not affected) by water. The yogin who has great understanding [mahämati] is the one who is similar to the person who, armed with mantras that counteract poison and the like, is not deluded by the poison even while devouring it."

I thank Shaman Hatley for answering several queries I had about this passage. 
that it is the matter of śuddhi and aśuddhi, as in was in ŚD 3.42cd-47, which is here (at TĀ 4.213cd) explicitly placed in question. The TĀ and TĀV go on to suggest that yogis know for themselves what is pure, what impure; and they further state that it is their very awareness that should determine how they act, for the normative rules of purity do not apply to them. ${ }^{47}$

Following this, the key objection is raised: are there not (Vedic) injunctions that require one to follow the rules of purity?48 The opponent asks, that is, whether tantric Brahmins must respect Vedic authority as well as Śaiva truths. How is it that, given the apparent validity or "truth" of both sets of śāstric injunction, the Vedic and the Śaiva, one can be invalidated, the other affirmed? How can one be internally a Kaula, externally a Śaiva, and a Vaidika in social practices when to be one sometimes requires one to contravene the strictures of the other?

The answer given not only suggests that it is not always inappropriate in practice to contravene the rules of purity and impurity, of śuddhi and aśud$d h i$; it further offers a rationale - a theory-for this complex of practice. This it does by invoking a general, and common, śāstric sensibility, namely, that the śāstras operate by first issuing blanket rules, which may later be superseded in certain specified contexts. This is a fundamental organizational structure of, among other śāstric works, ${ }^{49}$ the system of Pānini's Aștādhyāylu —which (as is well known) sets out exhaustively to account for correct speech not by listing every possible form of speech, but by structuring classes of rules that first define the utsarga or generally applicable rule, only then to itemize the apavädas or

47 See TĀ (and TĀV ad) 4.228ab (vol. 3, p. 249, lines 4-12):

yoginam prati sā cāsti bhāveșv iti viśuddhatā $\mid 4.288 \mathrm{ab}$

paśuprāyānāạn hi mantreșv api śivātmatvena parijñānam nāsti iti tān prati teșāṃ svakāryakāritvābhāvāt saṃbhāvanīyam api aśuddhatvam. dharādīnām ca yoginaṃ prati tatparijñānam asti iti teșām api viśuddhatvam. etad eva hi nāma yogino yogitvam, yat nikhilam idam viśvam śivātmatayā parijānāti iti.

"'As regards the yogin, moreover, that purity exists with respect to (all) entities.'

Indeed, the majority of bound souls do not perceive even (Śaiva) mantras as having Śiva-nature, and therefore they suppose them to be impure, since they fail (even) to perform their own duties (in employing these mantras). But, as for the yogin, he perceives (everything,) beginning with the earth(-tattva), as having that [Śiva-nature]. Therefore, (he perceives that) all of them without exception are completely pure. Indeed, this alone is the very nature of the yogin as a yogin, that he perceives this entire universe as possessed of Śiva-nature. This is definitive." "Objection: a fixed knowledge of purity, impurity, and so on exists by way of (Vedic) injunction(s) [codanayā]."

It is of course a model found in the Mīmāmsāa, as well, for example. 
exceptional rules that can override the former in the appropriate contexts. So much is explained in Patañjali's Mahābhāșya as follows:50

Now, one may object by asking whether it isn't the case that, when this (system of) instruction of (correct) speech is operative, one must recite each word in the course of acquiring the (correct forms of) words. (That is:) Every word must be recited, as in 'cow, horse, man, elephant, bird, deer, Brahmin.' Reply: Certainly not! It is not expedient to recite each word in the course of acquiring the (correct forms of) words. For, so much has been communicated as follows: 'Brhaspati imparted to Indra the study of words by uttering each one individually over the course of a thousand divine years, and he did not reach the end of it.' Brihaspati was the teacher [pravaktr], and Indra was the student [adhyetr]; and the time of instruction did not reach its terminus over the course of a thousand divine years. What of (the use of this method) today? One who plainly lives a long time (today) lives for (only) a hundred years ... How, then, should these (correct) words be acquired? A certain characteristic associated with the generic [sāmānya] and the particular [viśeșa] should be activated, by means of which [people] can-with little effort-become acquainted with the extremely massive flood of words. What, pray tell, is that? Utsarga and apavāda. A general rule [utsarga] is (first) to be employed; (then,) an exception [apavāda](, which overturns the general rule). But under what circumstances is the general rule to be used, under what circumstances the exception? The general rule is to be used generically. E.g.: karmany an (A 3.2.1). The exception to it (should be used) in a particular circumstance. E.g.: āto 'nupasarge kaḥ (A 3.2.3).

See Paspaśāhnika (7) of Patañjali's Mahābhāșya: utsarga and apavāda, vol. 1, p. 5, line 24 and following of the Kielhorn edition: athaitasmiñ śabdopadeśe sati kim śabdānām pratipattau pratipadapāṭhạ̣ kartavyaḥ. gaur aśvaḥ puruṣo hastī śakunir mrgo brāhmaṇa ity evamādayah śabdāh pațhitavyāh. na iti āha. anabhyupāyaḥ eșaḥ śabdānām pratipattau pratipadapāțhah. evam hi śrüyate. bṛhaspatir indrāya divyaṃ varșasahasraṃ pratipadoktānāṃ śabdānāṃ śabdapārāyaṇaṃ provāca na antam jagāma. brhaspatiś ca pravaktendraś ca adhyetā. diryam varșasahasram adhyayanakālaḥ na ca antaṃ jagāma. kim punar adyatve. yah sarvathā ciraṃ jīvati sa varșaśatam jīvati ... kathaṃ tarhīme śabdāh pratipattaryāh. kiñcit sāmānyaviśeșaval lakṣaṇaṃ pravartyam yenālpena yatnena mahato mahatạ śabdaughān pratipadyeran. kim punas tat. utsargāpavādau. kaścid utsargah kartavyaḥ kaścid apavādaḥ. kathañjātīyakạ̣ punar utsargạ̣ kartavyạ̣ kathañjātīyako 'pavādaḥ. sāmānyenotsargaḥ kartavyah. tad yathā. karmany an. tasya viśeșenāpavādah. tad yathā. àto 'nupasarge kah. 
Here, we see that it is for efficiency's sake that this model is adopted. And we are given a sample application in Pạnini's grammar, the details of which are explained in Appendix A. Essential to recognize is the fact that the prescription delineated by the general rule, the utsarga, always stands; yet, on some occasions its application is suspended by a special prescription, in the defined context of the apavāda or exceptional rule. ${ }^{51}$ Whenever no apavāda applies, however, the utsarga automatically prevails, for whenever or wherever the special rule does not apply (or must itself be suspended), one reverts by default —invariably and automatically— to the general, standing rule.

It is this very śästric mode that is explicitly invoked by Jayaratha in reference to the very phenomenon we have here, that of a complex of religious practice, Vedic and Śaiva. ${ }^{52}$

TĀ 4.23oab: 'If you argue that this [Śaiva rule] is invalidated by the Vedic one, (we reply:) why shouldn't it be the other way around?'53

$\cdots$

Considering that one may object by asking how it is that both [śāstras] are equally real, given that in certain contexts the injunction(s) [vidhi] associated with purity and the like are invalidated, even though they apply universally, for all people, [Abhinavagupta] says:

51 Note, therefore, that the domain of application of the general rule is said to be ubiquitous (sarvatra) at both Käśikāvrtti ad A 3.2.1 (which reads, in part: sarvatra karmanyy upapade dhātor anpratyayo bhavati) and in Jayaratha's explanation of the matter, at TĀV ad TĀ 4.23ocd-231ab, for which see below.

$5^{2}$ See TĀ 4.230-232ab (vol. 3, p. 253, line 1 to p. 255 , line 16), along with the corresponding passages of the TĀV (though one should note that, for the sake of brevity, none of the commentary is here cited of what follows TĀ 4.23oab, excepting the avataranika $\bar{a}$ that introduces 4.23ocd-231ab; and only part of the commentary that appears prior to TĀ 4.231cd-232ab is quoted here below):

vaidikyā bādhiteyam ced viparītam na kiṃ bhavet $\mid$

... nanu katham anayor aviśiștạn sattvam śuddhyādividhe h sarvapurușavișayatayā pravṛttāv api kvacid vișaye bādhät ity āśainkyāha

samyak cen manyase bādho visisțtavișayatvatah. 4.230

apavādena kartavyah sāmānyavihite vidhau |

yadi nāma bādhāvrttam samyag avabuddhyase, tan na kasyā api codanāyāh sattva-

hāniḥ. tathā hi-niravakāśatvād viśeșātmā apavādavidhị sarvatra labdhāvakāśam sāmānyātmakam utsargavidhiṃ bādhate, itiv vākyavidạ̣ ...

śuddhyaśuddhì ca sāmānyavihite tattvabodhini. $\quad 4.231$

pumsi te bādhita eva tathā cātreti varnitam |

53 This is of course to say, in a rhetorical manner, that it is rather that precisely the opposite must be the case. 
TĀ 4.23ocd-231ab: 'If you think about it clearly, a rule that is an exception $[a p a v \bar{a} d a]$ invalidates a rule generally applied [sāmānyavihita vidhi], because it applies in a particular domain.'

So, if you properly consider the procedure of invalidation, then (you will realize that) no injunction [codanā] whatever loses reality [sattvahāni]. To explain: the rule that is the exception [apavädavidhi] —by nature specific because it is (generally) void of any occasion (for application)supersedes the general rule [utsargavidhi], which, being one that always has met with its occasion (for application), is by nature generally applicable [sāmānyātmaka]. This is what those who know language say ...

TĀ 4.231cd-232ab: 'Moreover, purity and impurity, which are generally enjoined, are simply superseded when a man knows reality. This is how it has been explained here [in the Mãlinivijayottara].'

In the face of the objections of a more orthodox opponent who demands to know how the less permissive rules of the Veda cannot prevail over Śaiva scriptures, Abhinavagupta brilliantly inverts the hierarchy by appealing to a mainstream sāstric interpretive rule: it is the exception that preempts the normative, overarching rule and not the other way around. The rule that applies most generally, the Vedic one, is the utsarga. It is invariably prescribed-Jayaratha here described the utsarga as sarvatra labdhāvakāśa and sāmānyātmaka-but it is occasionally superseded by the exceptional rule or apavāda (described by Jayaratha as niravakāśatvād viśsșātmā), where in this instance the apavāda is the Śaiva rule, occasioned as it is by the special knowledge of the accomplished yogin who sees reality for what it is, as transcending the conventions of social position as determined by birth.

Nevertheless, whenever this special rule does not prevail—viz., outside the confines of tantric knowledge and practice - one must revert by default to conforming to the general rule, the utsarga (i.e., the Veda-based strictures), which is never nullified but only occasionally and temporarily superseded. So much is the position Abhinavagupta articulates in the TĀ, and Jayaratha indicates that in doing so he responds to the potential criticism that tantric rules authorize practices that are proscribed by Vedic norms, implying thereby that the tantric practices should be abandoned. This complex of practice, offered by Śaivas who engaged in rites that transgressed social and other contemporaneous cultural norms, was thus said to be the necessary product of the mainstream theoretical model that they understood to prescribe it.

The implications of this exemplar, then, are evident. Divinely sanctioned (in no small part by the authors' identification with Śiva), the Pratyabhijñā offers a tradition that prescribes exceptional practices that were introduced 
in historical time but are nevertheless rooted in an "ahistorical" authority. The knowledge it offers is fixed in its dimensions: there is no theology of "progress" in this śāstra. Each śāstra, moreover, Vedic and Tantric, speaks in a voice that in some important sense offers not merely a "knowing how," but rather a "knowing that"; for each individually denies the possibility of a dialectical relationship between theory (śästra) and practice (prayoga) in Pollock's sense of the problematic. (New political developments could not alter its vision of the nature of Śiva as a ubiquitous consciousness, for example.) To this extent, then, Pollock's model is applicable to these śāstras.

Yet, the tantric śāstra here placed under study nevertheless allows for a theology of novelty, because its "ahistorical" authority was said to have been introduced by particular agents in particular historical moments. The system thus allowed for, indeed anticipated, the emergence of new exceptional rules, and because the canon remained open, it was ever possible that another text, a new apavāda as it were, could emerge in a context in which the general parameters of social action—of religious practice or prayoga —otherwise and inevitably would remain operative.

A dialectic, then, between theory and practice in premodern South Asia, while it might not be found in the self-representation of any single given work, can be found in the proliferation of multiple śāstras, which in supplementing as well as competing with one another could accommodate innovation, explicitly or implicitly, by introducing novel theoretical models as circumstances warranted. The dialectic may only be found in the scriptural gestalt, however; for, it is only by reading multiple scriptural sources with an awareness of their mutually shared contexts, pedigrees, and, most importantly, structured mutual relations that one might begin to identify patterns of religious (and other forms of) change in Indian premodernity. ${ }^{54}$

54 In response to two important observations of Shaman Hatley, who read an earlier draft of this essay, two caveats are here required. First, I wish herein to indicate not that the Pratyabhijñã authors innovated the practice of deriving authority from their siddhahood. This is a practice that indeed predates these authors. Rather, I wish to suggest that such a practice, and others like it such as the avatära theory, allowed for innovations in tradition-they allowed authors self-consciously and explicitly to introduce unprecedented practices and ideas, what would be new in human history, as those that were religiously - transcendently — sanctioned. Thus, in an example offered from the avatära theory, Kṛșna deploys novel — and context-appropriate—ways of upholding dharma, even if he is himself ultimately considered to be an emanation of the timeless and transcendent Viṣnu himself.

Second, it can be observed (as Hatley did in a personal communication, via email, of November 11, 2015) that the social model that Abhinavagupta has developed is in fact also quite conservative, for while allowing for an innovative social institution that ignores caste 
I note, in closing, a concentric series of five implications of this phenomenon, each of an increasing degree of generalization, and in doing so I intend to point to possible avenues of further inquiry that lie beyond the scope of the present (and admittedly particular) case-study. The first involves a relatively narrow methodological concern in the study of Śaiva post-scriptural sources: the present exemplar stands as a reminder that knowledge of the wider context of "orthodox" śästric texts and concerns should inform scholarly interpretations of the post-scriptural literature; for even works that are primarily rooted in and explicitly concerned with esoteric scriptures, as is the TĀV, fre-

distinctions it also synchronizes such practices with the caste-based Brahminical strictures that were not, historically speaking, espoused in the Kula-Kaula branch of Śaivism; and it limits the transgressive practices by defining them as exceptional, as the (rare) contravention of the overarching, normative structures of Brahminism. (Similarly, Alexis Sanderson, in response to the shortened version of this essay that I presented at the conference held at the University of Toronto in his honor, suggested that what is offered here is a "vertical" model of authority and innovation, as opposed to the more radical, "horizontal" models found elsewhere in the Śaiva traditions, which more fully unshackled themselves from Brahminical norms.) This cannot be denied. There is, in the complex of theory and practice offered by the Pratyabhijñā, a certain preservation of Veda-based tradition. And it is true that there were in premodern South Asia models of change that sought not to modify (as Abhinavagupta does) but to upend Brahminical norms. Yet, a distinction here must be made between the degree to which these traditions in fact changed social norms and the fact that they explicitly and self-consciously wedded themselves to the idea that religion could offer ideas and practices that were explicitly said to be new. To put the matter differently, one might reasonably argue that Abhinava was somewhat inimical to (social) change-not entirely so, as what he endorses clearly also allows for the contravention of Brahminical norms, in part at least; but he also explicitly does not espouse a view that change is inimical to religious ideas and practices. If it is indeed the case that he-and Utpaladeva — sought to preserve a certain Brahminical order (in part at least), reigning in or domesticating, as it were, the more radical practices of Śaiva and Śākta traditions, it is all the more noteworthy that they did so by explicitly endorsing the possibility of religious change — of changes in ideas and social and other practices — in doing so; for this strategy speaks to the very fact that change, in premodern South Asia, was not inimical to religion, even if, as one might argue, the fact that they said as much was done in service of limiting social change to modifications of Brahminical norms, rather than allowing for the wholesale rejection of them. My own view, as is clarified in the conclusion, is that the model here presented - of change through modification of the normative order-both embraced the idea of change and ushered in changes "on the ground" in religious and social practice; moreover, I maintain that it offers what was the prevalent model of change in premodern South Asia - that of change through modification as opposed to wholesale change or revolution-and scholars should look for such types of change in places where previous scholarship has only seen a static social and intellectual order. 
quently record a substantial interaction with the mainstream systems of learning (including both various śāstric systems such as Pānininian grammar and the classical philosophical darśanas).

Second, there is the matter of the social context, the Kashmir Valley of the period in question, in which the authors of the Pratyabhijñā lived and wrote. While it is worth noting that the tantric initiatory "family" (kula) would have frequently offered an uncomfortable home for low-caste and outcaste initiates (as many or few as there might have been in practice), entry into the tantric kula could also have afforded the initiate a certain place of privilege. Initiation was, from the perspective of the tradition, a significant institution, one that the tantric practitioner would have coveted and shared sparingly; and membership would have conferred not only a certain prestige but also a special form of knowledge that those within the tradition would have held to be paramount: a certain access to the divine.

Thus, while this form of privilege does relatively little globally to address the social inequities enshrined in normative, caste-based strictures, the initiation of low-caste or outcaste individuals into the secret śāstras nevertheless constitutes a social innovation over and against preexisting Vedic (or, perhaps more accurately, dharmaśästric) norms. The change it offers, however, comes not in the form of social revolution but in the form of a particular and circumscribed social inclusion. Generalizing from the present exemplar, one suspects that social change in premodern South Asia will most often be found in its incrementalism, as opposed to efforts in total revolution such as the toppling of the institution of royal sovereignty or the wholesale displacement of Brahminical authority. Social change, simply, will likely be found, where it is to be found, in the often-subtle exceptions that contradict overarching and often oppressive rules that were more globally applied, in Kashmir or elsewhere, in premodern South Asia.

Third, the model of social conduct witnessed in the Pratyabhijñā exemplar finds correspondences in the narrative tropes of (non-tantric) Śaiva mythology. Siva is not only paradoxically erotic and ascetical in the mythological literature, as is well known, but he also appears there as both asocial or anti-social and integrated into society (and often simultaneously so), as is also well known. Take, for example, the insult of Dakșa's sacrifice, where Śiva is depicted as a pariah while simultaneously standing as the ideal husband in the eyes of the eminently acceptable Sati. One may therefore query whether the sort of complex of social practice examined in the present essay constitutes a phenomenon more widely attested across various Śaiva traditions. ${ }^{55}$ 
Fourth, the exceptionalism offered by the utsarga-apavāda model is commonly attested across a range of premodern Indian cultural systems, most notably, for the purposes of the present essay, those that address social rules and life. The Kṛ̣na of the Mahäbhärata plainly contravenes a series of generally applicable social strictures, for example, rules that he otherwise would wish vigorously to maintain; and the rules of conduct for crisis-situations (apaddharma) more generally are premised on the idea that the prescribed actions are exceptional both because they contravene otherwise normative behaviors and because they are deemed inactionable outside the only context in which they may apply: that of a social emergency. And one cannot overlook, in this context, the frequency with which the Veda is acknowledged as authoritative in Hindu traditions while the contents of Vedic works are nearly entirely ignored. It is common, in sum, to find a layering of practice in South Asian religion and social life; and such complexes of practice, allowing as they do for the exception, in its place, to supersede normative strictures, should probably be counted as the normative model of social organization in premodern South Asia. ${ }^{56}$

Fifth and finally, I address an issue relevant to the study of religion, broadly conceived. It is instructive that Pollock appealed to Geertz in formulating the theoretic that defines his understanding of the relationship of śastra to prayoga. Indeed, he finds Geertz's famed distinction of "models of" from "models for" precisely in the article in which he famously defines religion as "(1) a system of symbols which acts to (2) establish powerful, pervasive, and longlasting moods and motivations in men by (3) formulating conceptions of a general order of existence and (4) clothing these conceptions with such an aura of factuality that (5) the moods and motivations seem uniquely realistic." 57

Geertz apparently did not anticipate the possibility of a complex of (sometimes mutually-contradictory) beliefs or a complex of (sometimes mutuallycontradictory) practices. His model instead elaborates a more singular structure or phenomenon, referring as it does to " $a$ system of symbols" that establishes powerful moods and motivations in men by formulating " $a$ general order of

themselves for examination along these lines, the anti-caste Vīraśaivas immediately come to mind.

$5^{6}$ Indeed, the sort of "And" approach that Pollock identifies and endorses (over and against an "Either/Or" approach) elsewhere in his writings owes something, I think, to this intellectual practice of allowing for exceptions in the context of an overarching normative practice that otherwise prevails. See Pollock 2006, 574-580. Cf. footnote 59 . 
existence," which is clothed in "an aura of factuality," all of which implies a model of a singular source of religious authority. There is in this, as in other similarly situated definitions, ${ }^{58}$ an understanding of religion as involving an appeal to an ultimate that does not seem naturally to allow for variegated and equally legitimate sources of authority, that fails to account for the type of "And" model found in South Asia and, one imagines, elsewhere, as well:59 and in defining religion in this manner, we see foreclosed any possibility that a religious tradition might innovate or simultaneously access disparate sources of authority in order to recommend diverse — or even new—doctrines and/or practices, as we see in our premodern Indian exemplar.

The example here studied, then, begs for novel theoretical models of religion, ones that could attend more fundamentally or at least more explicitly to the capacity of religion to accommodate, indeed self-consciously to cultivate, change. To proffer as much would refocus our possible ways of reading premodern religious traditions, allowing us to identify patterns of social and religious change that are not defined by modern understandings of the same (as exemplified in Pollock's dependence on the concept of "progress" to measure any conceptual openness to social change in India's premodernity). It would also require one to cultivate a view of religion that emphasizes not its interest in certainty, in its capacity to memorialize particular ways of acting or models of knowing - be they models of "knowing that" or "knowing how"-but its interest in possibility. Cultivating such a new model (and thereby a new interpretation, even a new scholarly definition) of religion could, that is, nurture a view of religion that emphasizes its more active and dynamic, and malleable and practical, dimensions, the capacity of religious practitioners and authors themselves self-consciously to formulate systems of understanding and to stake claims where any number of claims could have possibly been made.

$5^{8} \quad$ For example, Durkheim's definition of religion reads as follows: "A religion is a unified system of beliefs and practices relative to sacred things, i.e., things set apart and forbiddenbeliefs and practices which unite in one single moral community called a Church, all those who adhere to them." So too could it be said of a number of others, such as Melford Spiro's famed and widely accepted definition of religion as "an institution consisting of culturally patterned interaction with culturally postulated superhuman beings." These and other, similarly-oriented definitions all, if they do not demand it, implicitly lean on the notion that what can be true or significant is something similar to a singular ideal, rather than allowing for the sorts of nuanced and contextually situated notions of what counts that we can find in our Indian exemplar.

59 I here follow Pollock in distinguishing between the "And" model offered in South Asia and the "Either/Or" model articulated elsewhere. See Pollock 20o6, $574-580$; cf. footnote 56. 
This would, in short, require one to understand religion not primarily as the maps of systems and symbols and practices that are charted by religious agents, but instead in terms of the strategies they use to sketch their maps. Those who have crafted religious ideas and ideals, I think, were - and are-well aware of the fact that religions offer changing models of action and modes of reflection in the context of a changing world that is perennially met with novel problems, begging resolution. Those of us who read and theorize their practices should, in turn, seek to shape our reflections on religion in a manner that allows more naturally for the innate flexibility, the freedom of possibility — of change — in idea and practice, with which religious agents developed and develop their models for action.

\section{Abbreviations}

A Aștāadhyāȳō of Pāninini

İPK IÍsvarapratyabhijñākārikā of Utpaladeva

İPKVṛ İśvarapratyabhijñākārikāvrtti of Utpaladeva

İPV İśvarapratyabhijñāvimarśinī of Abhinavagupta

İPVV İśvarapratyabhijñāvivrtivimarśinī of Abhinavagupta

KSTS Kashmir Series of Texts and Studies

ŚD Śivadrșți of Somānanda

ŚDVṛ Śivadrșțivrtti of Utpaladeva

TĀ Tantrāloka of Abhinavagupta

TĀV Tantrālokaviveka of Jayaratha

\section{Acknowledgements}

I would like to thank Srilata Raman and Shaman Hatley for inviting me to the conference in honor of Alexis Sanderson, titled "Śaivism and the Tantric Traditions," at which I presented a shortened rendering of this essay. I also thank Eric Steinschneider for all he did to facilitate the running of this well-organized event. Prior to this, I delivered an earlier version of this essay in the Hindu Studies Colloquium at Harvard Divinity School on February 20, 2014. I thank Anne Monius for the invitation to speak there and for her thoughtful and instructive comments on my lecture. I also thank Ben Williams and James Reich for their comments on my lecture and for their hospitality during my time in Cambridge, MA. Finally, I thank Shaman Hatley for having read a draft copy of this essay and for the insightful comments and suggestions he offered in doing so. 


\section{Appendix A: utsarga and apavāda as Exemplified in Aștādhyāȳ}

(A) 3.2.1 and 3.2.3

\subsection{1. karmany an.}

3.2.3. āto 'nupasarge kah.

1. The Pāninian example here offered is of a general rule, or utsarga, that is preempted by a special rule, or apavāda, in a particular circumstance. The general rule is offered at Asțādhyāyi (A) 3.2.1; the special rule is subsequently given at A 3.2.3. The rules here are used to generate what are referred to as upapadasamāsas.

2. A principal purpose of the grammar, of course, is to allow one to generate the correct form of speech by the application of a series of rules that build, as it were, the correct form of speech in a series of operational steps. The point of the present example is that the general rule, A 3.2.1, regularly —indeed, always — applies, ${ }^{60}$ unless the parameters of the special rule, A 3.2.3, apply, in which case the general rule is suspended. If the special conditions that trigger the special rule are not met, the general rule is reverted to as authoritative and is applied.

3. A 3.2.1. states that the affix an is added after a verbal root (dhätoh is to be read into A 3.2.1 by anuvrtti, or ellipsis, from a preceding rule) when the object of the verb is in composition with it as an upapada. This yields, e.g., kumbhakāra ("potter") and nagarakāra ("city-builder"); kāṇdalāva ("branch-cutter") and śaralāva ("reed-cutter"); and vedādhyāya ("the learning of the Veda") and carcāpattha ("the reading of Carcā"). In each of these cases, the final " $a$ " of each word is present because of the affixation of $a n$. (The $a$ of $a n$ is precisely this letter or akșara, while the $\underline{n}$ of an is a "marker," an anubandha or it, which is dropped out in the derivational process and does not appear in the final form of the given word or words being derived, though it does serve to trigger certain rules and operations in the grammar, and so has a meta-function in the derivational process.)

4. On the other hand, the affix an is not allowed to be added in cases where the special rule found in A 3.2.3 does apply. This rule states that the affix $k a$ will come after a verbal root that ends in " $\bar{a}$," if and only if the verbal root in question is not preceded by a preverb (upasarga), and only when

6o Note that so much is made clear by the Kāśikāvrtti ad A 3.2.1, which reads in part as follows: sarvatra karmaṇy upapade dhätor anpratyayo bhavati. 
the object of the verb is in composition with it (karmani here is extended from A 3.2.1 to the present rule by way of anuvrtti or ellipsis). Examples of the application of this special rule are: goda ("giver of cows") and kambalada ("giver of a blanket"). In both of these examples, the final " $a$ " of each word is present because of the affixation of $k a$. (The $a$ of $k a$ is precisely this akșara, while the $k$ of $k a$ is again a "marker" or anubandha/it that is dropped out in the derivational process and does not appear in the final form of the word being derived.)

5. If we were to have been able to use the affix an instead of the affix $k a$ in the present pair of examples, we would have been required to preserve the long $\bar{a}$ in the verbal root $d \bar{a}$, which is present in both examples (goda and kambalada), generating thereby the wrong forms. Using rule 3.2.1 instead of 3.2.3 (and thus using an instead of $k a$ ) would give us the wrong forms *godā and *kambaladā in place of goda and kambalada. This would be bad!

6. Similarly, in an instance where the verb employed does take an upasarga or preverb, we have an exception to the special rule, which prohibits the use of $k a$ in place of $a n$ precisely when there is a preverb affixed to the verb. Thus, even when the verbal root in question ends in long $\bar{a}$ and is in composition with its object as an upapada, rule 3.2.3 cannot apply. A pair of examples is given with the verbal root $d \bar{a}+$ sam. The apavāda rule (A 3.2.3) is not allowed to take effect, and therefore $k a$ is not appended to the verb. Thus, we derive gosamdāya ("who ceremoniously gives a cow") and vadabasamiāya ("who ceremoniously gives a vadaba horse"), and here the final vowel $(a)$ of each term is the product of $a n$ and not $k a$.

7. What is at stake in this last pair of examples (viz., those of gosamdāya and vadabasamdāya) is the status of the long vowel $(\bar{a})$ in the verbal root $d \bar{a}+$ sam. If the affix $k a$ were used in the present examples, then the "marker" (anubandha, it) $k$ would have triggered another rule of the grammar (A 6.4.64, see paragraph 10, below), one that deletes this long vowel. If this marker $(k)$ is not in play, on the other hand, as it is not, for example, when the affix marked with the anubandha $\boldsymbol{n}$ is used (as in an of A 3.2.1.), then the rule in question that deletes the long $\bar{a}$ does not apply.

8. So, to review before concluding: we here have a general rule, A 3.2.1, which applies generally. It is the utsarga. We have a special rule or apavāda (A 3.2.3) that applies within what otherwise would have been the domain of this general rule, but which is commanded by the special rule under special circumstances, with the application of the special rule blocking the application of the general rule or utsarga. 
9. How does this figure in the present example? Well, A 3.2.3 should apply wherever we have the requisite special circumstances, namely whenever a verbal root ending in " $\bar{a}$ " is in composition with its object as an upapada, as it did in the derivation of goda and kambalada. But the apavāda rule (A 3.2.3) does not apply in the derivations of gosamdāya and vadabasamdāya, even though in both cases we have a verbal root that ends in $\bar{a}$ and that is in composition with its object as an upapada. This is so, because in both cases the verbal root appears with a preverb (upasarga), and A 3.2.3 specifies that it can apply only in instances when there is no preverb (it reads: anupasarge).

10. Because the examples gosamdāya and vadabasam dāaya include a verbal root that appears with an upasarga (the verb is $d \bar{a}$, the upasarga or preverb is sam, of course), they are no longer to be marked by $k a$. This is significant because of what $k$ does: according to A 6.4.64 (äto lopa iți $c a$ ), the final $\bar{a}$ would have been elided, the rule effecting as much either because it appears before an ärdhadhātuka suffix (defined at A 3.4.114) augmented with it, or when the affix begins (as would have been so in the present instance) with a vowel and has an indicatory marker (aunbandha or it) of $k$ or $\dot{\boldsymbol{n}}$ (the affix $a$ in $k a$ begins with a vowel- $a$ of course being a vowel and the first member of a single-lettered affix-this after taking into account that the $k$ is a marker and not a part of the affix itself). ${ }^{61}$

11. Thus, in these instances A 3.2.3 does not apply. And here is the key to understanding the present example of utsarga and apaväda: the utsarga or general rule (i.e., A 3.2.1) is thus again deemed operative and automatically so, by default. This is so because it is understood always to apply, only excepting when an apavāda overrules or suspends it. What this means is that there is no need to write yet another rule to account for the derivation in instances where the rule of exception or apavāda is itself rendered inoperative by an exception; for upon the suspension of the apava ada rule, the utsarga is immediately and automatically understood once again to apply. As such - returning now to the pair of examples here reviewed - the final $a$ of gosamdāya and vadabasamdāya results from an being applied, not $k a$. One returns to the original rule by default, thus providing for the final letter $a$ of both gosamdāya and vadabasamdāaya. And the anubandha $\boldsymbol{n}$, unlike $k$, does not trigger A 6.4.64 and thus does not lead

61 Note that the Kāśikāvrtti ad A 6.4.64 reads in part as follows: iḍādāv ārdhadhātuke kniti cākārāntasyāngasya lopo bhavati. 
to the elision of $\bar{a}$ in the verbal root $d \bar{a}$ appearing in both compounded words. In a word, apavādas can only be written in contexts where an utsarga is always otherwise operative.

\section{References}

\section{Primary Sources}

Asțādhyāȳi. See Kāśikāvrtti.

Ísvarapratyabhijñāāārikā. Raffaele Torella, ed. The İśvarapratyabhijñākārikā of Utpaladeva with the Author's Vrtti:Critical Edition and Annotated Translation. Rome: IsMEO, 1994.

İśvarapratyabhijñāakārikāvrtti. See İśvarapratyabhijñāakārikā.

İsvarapratyabhijñāvimarśinī. Madhusudan Kaul Shāstrī, ed. The İśvarapratyabhijñā of Utpaladeva with the Vimarśini by Abhinavagupta. Ksтs 22 and 23. Pune: Aryabhushan Press, 1918-1921.

İśvarapratyabhijñāvivrtivimarśinī. Madhusudan Kaul Shāstrī, ed. The İ́svarapratyabhijñā Vivrtivimarśini by Abhinavagupta. 3 volumes. KsTs 6o, 62 and 65. Pune: Aryabhushan Press, 1938, 1941, and 1943.

Kāśikāvrttti. Swami Dwarikadas Shastri and Pt. Kalikaprasad Shukla, eds. The Kāśikāvrttti of Vāmana-Jayāditya, with the Nyāsa or Pañcikā of Jinendrabuddhipāda and the Padamañjarĩ of Haradatta Miśra. 6 vols. Prachya Bharati Series 2-7. Varanasi: Pracya Bharati Prakashan, 1965.

Tantrāloka. Paṇ̣it Mukund Rām Shaāstrī (vol. 1) and Paṇ̣it Madhusudan Kaul Shāstrī (vols. 2-12), eds. The Tantrāloka of Abhinava Gupta, With Commentary by Räjānaka Jayaratha. 12 vols. KsTs 23, 38, 30, 36, 35, 29, 41, 47, 59, 52, 57 and 58. Allahabad: The Indian Press Ltd. (vols. 1, 5-6); Bombay: Nirnaya Sagar Press (vols. 7, 10-12), Tatva-Vivechaka Press (vols. 3-4, 8-9), and Shri Venkateshvar Steam Press (vol. 2), 1921-1938.

Tanträlokaviveka. See Tantrāloka.

Mahābhāssya. F. Kielhorn, ed. [188o-1885], revised by K.V. Abhyankar (1972-1996). Vyākarana-Mahäbhāsya of Patañjali. 3 vols. Bhandarkar Oriental Research Institute, Poona, 1996-2005.

Śivadrșți. John Nemec, ed. The Ubiquitous Śiva: Somānanda's Śivadrsțti and His Tantric Interlocutors. New York: Oxford University Press, 2011.

Śivadrsțti. Madhusudan Kaul Shastri, ed. The Śivadrsți of Somānandanātha with the Vrtti by Utpaladeva. Ksts 54. Pune: Aryabhushan Press, 1934.

Śivadrștivittti. See Śivadrșți. 


\section{Secondary Sources}

Dyczkowski, Mark. 1987. The Doctrine of Vibration: An Analysis of the Doctrines and Practices of Kashmir Shaivism. State University of New York Series in the Shaiva Traditions of Kashmir. Albany: State University of New York Press.

Edelmann, Jonathan. 2014. "Introduction: Innovation in Hindu Traditions." Special issue: Innovation in Hindu Traditions. International Journal of Hindu Studies 18 (2): $113-118$.

Geertz, Clifford. 1973. "Religion as a Cultural System." In The Interpretation of Cultures: Selected Essays. New York: Basic Book.

Macdonell, A.A. [19oo] 1962. A History of Sanskrit Literature. Reprint, Delhi: Motilal Banarsidass.

Mohanty, J.N. 2010. A Dictionary of Cultural and Critical Theory, edited by Michall Payne and Jessical Rae Barbera. Second Edition. Oxford: Wiley-Blackwell.

Monier-Williams, M. 1891. Brāhmanism and Hindūism; Or, Religious Thought and Life in India, As Based on the Veda and Other Sacred Books of the Hindūs. 4th edition. New York: Macmillan and Co.

Nemec, John. 2011. The Ubiquitous Śiva: Somānanda's Śivadrșți and his Tantric Interlocutors. New York: Oxford University Press.

Nemec, John. 2013. "On the Structure and Contents of the Tridaśadāmaratantra, A Kaula Scriptural Source of the Northern Transmission." Journal of Hindu Studies 6 (3): $297-316$.

Nemec, John. "Kashmir." 2015. Oxford Bibliographies: Hinduism, edited by Alf Hiltebeitel. New York: Oxford University Press. October 26, 2015. doi: 10.1093/OBO/97801953 99318-0156

Pollock, Sheldon. 1985. "The Theory of Practice and the Practice of Theory in Indian Intellectual History." Journal of the American Oriental Society 105 (3): 499-519.

Pollock, Sheldon. 1989. "Mīmāmsāa and the Problem of History in Traditional India." Journal of the American Oriental Society 109 (4): 603-610.

Pollock, Sheldon. 1993. "Deep Orientalism? Notes on Sanskrit and Power Beyond the Raj." In Orientalism and the Postcolonial Predicament, edited by Carol Breckenridge and Peter van der Veer, 76-133. Philadelphia: University of Pennsylvania Press.

Pollock, Sheldon. 2006. The Language of the Gods in the World of Men: Sanskrit, Culture and Power in Premodern India. Berkeley and Los Angeles: University of California Press.

Ratié, Isabelle. 2011. Le Soi et l'Autre: Identité, différence et altérité dans la philosophie de la Pratyabhijñā. Jerusalem Studies in Religion and Culture, vol. 13. Leiden: Brill.

Sanderson, Alexis. 2005. "A Commentary on the Opening Verses of the Tantrasāra of Abhinavagupta." In Sāmarasya: Studies in Indian Arts, Philosophy and Interreli- 
gious Dialogue, edited by Sadananda Das and Ernst Fürlinger, 89-148. New Delhi: D.K. Printworld.

Smith, David. 1985. Ratnākara's Haravijaya: An Introduction to the Sanskrit Court Epic. Delhi: Oxford University Press. 